\section{Graduate balancing act}

\author{
With industry poaching the best science \\ graduates, US universities face a dilemma
}

FAMILIARITY more often breeds indifference than contempt. That is the chief lesson to be drawn from this week's report from Washington (see opposite) of the latest wave of alarm about the condition of graduate education in the United States. It is now well over three years since a joint commission of the National Science Foundation and the then Department of Education spelled out the problems that have since become still more apparent: shortages of able teachers in fields where universities cannot compete as employers with industrial corporations, surpluses of teachers in fields (mostly in the arts and humanities) where students are now in short supply and a general lack of resources with which to ensure that even where teachers and students are appropriately matched, graduate education and research can be prosecuted as effectively as they might be. Such palliatives as there have been, the decisions separately by the National Science Foundation and the Pentagon to spend money on university equipment, and the tax relief offered to corporations supporting academic research, cannot by themselves be a remedy.

Electronics, computer science and related fields of study should provide the exemplar of a solution. The rapidly growing electronics industry relies on academic graduate schools for recruits to its growing labour force but is also predatory on university faculties whose members are potential employees of a particularly valuable kind. While even the richest universities cannot compete with the corporations in the direct monetary rewards they are able to offer, well-established academics are kept at their posts by the inherent interest of the jobs they do and by the opportunities that arise to supplement their academic salaries by consultancy. The rub comes with less well-established people, or with those who happen to work at universities whose reputations are not among the highest.

For what it is worth, the squeeze on the training of skilled people does not seem so far to have created insuperable problems. But there has not yet been time for the more subtle but perhaps more important difficulties to become apparent. How many of those now being hired will be able to contribute to their employers as fully as they might (and as their salaries suggest they should)? And how many of them have been sufficiently well-taught at graduate school to be able to hold their own in an industry most of all distinguished by its competitiveness? Prudent people thus affected will no doubt recognize the risks and may even reconcile themselves to periodic returns to graduate school during their careers. There is a case for asking that employers should more often than at present recognize the importance of what the graduate schools have to offer people in mid-career.

But who will teach? If too many academics have fled to industry, the graduate schools may even be too ill-equipped to undertake such important tasks. The simplest solution is that corporations in the shortage fields should follow the pattern common in Japan, making arrangements with university departments that will enable the departments to contribute directly to industrial development by means of formal development contracts. The result, in the short run at least, could be beneficial for both parties to these contracts and for graduate education as well. The snags, also evident in Japan, are that if such arrangements become permanent, or even too common, academic life must in the long run be damaged. University presidents looking to such bilateral arrangements to keep hard-pressed departments alive should be conscious of the dangers.

More serious difficulties arise in more traditional fields of study, where the pace of technological change is not nearly as rapid but where the need for trained people is still as great as ever. Many university departments of chemistry in the United States now find themselves less able than in the past to attract able graduate students, perhaps because the most able to have rushed off in other directions, perhaps because the traditional assump- tion that a graduate course would carry with it an opportunity to join a university faculty is now recognized to be an illusion and perhaps because of the much-publicized consequences of the recession for the industry. The chances are that potential graduate students have over-reacted to the changing pattern of the real world in which they will eventually have to work. The irony is that the future well-being of these industries may be jeopardized both by the fall in the numbers of graduate students being trained and also by the danger that the pool of academic research itself will shrink. These are the fields most in need of direct help from outside - from university administrations and from grant-making bodies such as the National Science Foundation. The modest sums so far spent on equipment can only scratch the surface.

The future for other fields of study is even more bleak. In the arts and the humanities, universities in the United States have been under pressure for the whole of the past decade. Now, for some of them, the pressure has become intolerable. Except in vocationally oriented fields of study such as law, there has been a decline in number of undergraduates as well as graduate demand. The result is that outside the major universities, faculty strength is being run down as quickly as can be managed. In the short run, universities have no alternative; in the long run, the result may be that universities are unable to provide the range of undergraduate teaching that society expects of them. Their capacity to provide a general education for undergraduates will be impaired, as will be their contribution to scholarship at large. The only effective remedy lies with the federal government, which should quickly increase the small pot of money from which research in the humanities is at present supported. The march by students towards fields of study thought to be useful in the job market, which will be welcomed in Washington, requires that the federal government should take steps to support the fields from which the stampede is taking place. The hope that Washington will see the problem in this way is, unfortunately, only small.

\section{Southern comfort}

\section{If Argentina becomes nuclear-free, will Brazil follow suit?}

NoBODY will be surprised that the new government in Buenos Aires is less keen than its military predecessors on making nuclear weapons, but the report of what has been said in Argentina (see p. 724) since last month's elections is encouraging. Since the late 1950s, Argentine governments have been blowing hot and cold about their plans for nuclear energy, apparently unabashed by the discovery that the first plan to harness thermonuclear fusion for purposes of all kinds collapsed in confusion and allegations of fraud. Since then, there has been a loose but far from perfect correlation between the military stripe of a government and its nuclear ambitions. (The first Peron government, which might have been expected to renounce military plans for nuclear energy, was instead studiously ambiguous.) More recently, the Argentine Government position has been an amalgam of the arguments that nuclear energy is economically essential and that signature of the Treaty of Tlatloco, which would make South America a nuclearfree zone if only Argentina and Brazil would join, would be politically compromising. So it will be interesting and important to see whether the time is now ripe for Argentina to take the plunge and for Brazil, contrary to rumours, to follow.

No country in South America can possibly have a serious interest in nuclear weapons. The political cost to a country which acquires them would consist not merely of deteriorating relations with near neighbours but the risk of intervention from outside. In a region where political boundaries have been uncannily stable while governments have come and gone, everybody would be the loser. The snag, hitherto, is that Argentina appears to have been unable to join the treaty because Brazil has stood out against it and that Brazil has followed exactly the same line. Is it now time for other South American governments (nobody from outside could help) to put pressure on the two laggards? 